\title{
Brand Preference towards Smartphones among College Students in Coimbatore City, Tamil Nadu.
}

\author{
G. Saranya, G. Yoganandan
}

\begin{abstract}
Consumers' preference towards branded smartphones has been focused as important in the current scenario. Therefore the objective of this study was to investigate the determinants of brand preference in Coimbatore city. This study employed descriptive statistics and Analysis of Variance. Data were collected in Coimbatore city among arts and science college students. Standard questionnaire has been distributed among the students and sample size for this study was 100 respondents using convenience sampling. The results showed that the smartphone manufacturers has to concentrate on high end features in the smartphones with advanced technology in order to fulfill the urge of the customers satisfaction and also to take steps to reduce the price of the smartphone because of the huge demand arises among customers. Brand price plays a major role because being college students the price has an impact in the purchase of smartphones.
\end{abstract} Students

Keywords: Brand, Consumer, preference, smartphone,

\section{INTRODUCTION}

Smartphone and mobile phone communication is not only the widely used mode of communication but also the essential gadget for each and every human being as a business man, employee, student, house wife, staff, officers, professionals. It has become a basic need irrespective of age, gender, income, education, occupation, area of residence etc. We cannot imagine a single day without smartphone because it reduces our time in sending emails, audio and video calling, video conferencing, downloading applications, online games and videos, educational websites, day-to-day current affairs, weather, directions etc. people expects more from the smartphone manufacturers in order to make their life easy and smooth going. The brand preference has influence in purchase decision making and consumer behaviour in deciding which brand to purchase.

\section{NEED OF THE STUDY}

There are number of branded smartphones available in the global market. Customers prefer to choose one brand over the other. Especially, College students purchase smartphones by comparing the features and advancements in the smartphones among wide range. This study is an attempt to find out the determinant that influence brand preference among college students.

Revised Manuscript Received on December 05, 2019.

* Correspondence Author

G. Saranya*, Periyar Institute of Management Studies, Periyar University, Salem, India. Email: gsaranyaphd@gmail.com

Dr. G. Yoganandan, Periyar Institute of Management Studies, Periyar University, Salem, India. Email: g_yoganandan@yahoo.com

\section{REVIEW OF LITERATURE}

Consumer behaviour is moderately noted as a comparison of an individual's self image with a product's brand image [1]. Buying decisions influence buying decisions and gain brand personality and reputation [2]. The six basic necessary conditions for brand preference are biased, behavioral response, expressed over time, decision making unit, alternative brands and psychological process [3]. Brand image is an expensive and time consuming process but it results in image creation or brand identity development [4]. Consumer preferences for various products or brands arise from different factors prices, durability, goals, attitudes and income [5]. Patriotism, protectionism and social economic conservatism are the features affecting consumer characteristics [6]. There is a positive effect on brand and consumer through customers' advice [7]. Brand helps the customers to identify and recognize products and their producers [8]. Brand has a positive reputation which is successful and profitable [9].

\section{OBJECTIVES OF THE STUDY}

To investigate the determinants of brand preference among college students in Coimbatore city.

\section{HYPOTHESES}

$\mathrm{H}_{0}$ : There is no significant relationship between demographic profile and brand preference

$\mathrm{H}_{1}$ : There is a significant relationship between demographic profile and brand preference

\section{MATERIAL, METHODS AND MEASUREMENT}

The population for this study was college students who were studying in arts and science colleges in Coimbatore city of Tamil Nadu. Both under graduate students and post graduate students were taken for this study through convenience sampling. Convenience sampling was adopted because during pilot study the college authorities refused to collect data inside the campus and to furnish the exact number of college students studying in their colleges. The response was collected from 5 colleges i.e., 20 students from each college has been selected. Standard questionnaire which has been proved already by many researchers has been taken and circulated among students and sample size taken as 100 respondents. Both primary data and secondary data have been used in this study. Primary data collected through questionnaire from the students and secondary data were taken from books, journals, magazines etc. The questionnaire consists of two sections. 


\section{Brand Preference towards Smartphones among College Students in Coimbatore City, Tamil Nadu}

First section deals with demographic profile of the students and the second section deals with the constructs of brand preference dimensions such as preference, repurchase intention, brand price, brand appearance and satisfaction. The collected data has been analyzed using Statistical Package for Social Sciences (SPSS) version 22.0

\section{RESULTS AND DISCUSSION}

\section{A. Percentage analysis}

\begin{tabular}{|c|c|c|}
\hline Variables & Frequency & Percentage \\
\hline \multicolumn{3}{|c|}{ Gender } \\
\hline Male & 82 & 82 \\
\hline Female & 18 & 18 \\
\hline \multicolumn{3}{|c|}{ Age } \\
\hline $18-21$ years & 78 & 78 \\
\hline $22-25$ years & 22 & 22 \\
\hline \multicolumn{3}{|c|}{ Degree } \\
\hline Under graduate & 79 & 79 \\
\hline Post graduate & 21 & 21 \\
\hline \multicolumn{3}{|c|}{ Stream/Discipline } \\
\hline Arts & 71 & 71 \\
\hline Science & 29 & 29 \\
\hline \multicolumn{3}{|c|}{ Family Monthly income (Rs) } \\
\hline Below 10000 & 14 & 14 \\
\hline $10001-20000$ & 33 & 33 \\
\hline
\end{tabular}

\section{Source: primary data}

Out of 100 respondents, 82 respondents are male and 18 respondents are female. 78 respondents come under the age group between $18-21$ years whereas 22 respondents' age group falls between $22-25$ years. 79 respondents are under graduate students and 21 respondents are post graduate students. 71 respondents are from arts stream whereas 29 respondents are from science stream. 14 respondents family monthly income is below Rs. 10000, 33 respondents family monthly income falls between Rs 10001 to 20000, 17 respondents family monthly income falls under Rs 20001 to 30000 whereas 36 respondents family monthly income falls between above Rs 30000. 56 respondents come from urban area, 19 respondents come from rural areas whereas 25 respondents come from semi-urban area.

Table 2 Reliability Analysis Test

\begin{tabular}{|c|c|c|}
\hline Variables & No. of Items & Cronbach's Alpha \\
\hline Brand Preference & 7 & 0.67 \\
\hline Repurchase Intention & 3 & 0.591 \\
\hline Brand price & 3 & 0.623 \\
\hline
\end{tabular}

\section{Source: primary data}

Table 3 One-Way ANOVA result based on respondents' age group

\begin{tabular}{|c|c|c|c|c|c|c|}
\hline Particulars & $\begin{array}{c}\text { Age } \\
\text { group }\end{array}$ & $N$ & Mean & $d f$ & $F$ & $\underset{\text { Value }}{p}$ \\
\hline \multirow{2}{*}{$\begin{array}{c}\text { Brand } \\
\text { Preference }\end{array}$} & $\begin{array}{l}18-21 \\
\text { years }\end{array}$ & 78 & 11.43 & \multirow{2}{*}{99} & \multirow{2}{*}{0.032} & \multirow{2}{*}{0.85} \\
\hline & $\begin{array}{l}22-25 \\
\text { years }\end{array}$ & 22 & 11.31 & & & \\
\hline \multirow{2}{*}{$\begin{array}{c}\text { Repurchase } \\
\text { intention }\end{array}$} & $\begin{array}{l}18-21 \\
\text { years }\end{array}$ & 78 & 9.67 & \multirow{2}{*}{99} & \multirow{2}{*}{4.93} & \multirow{2}{*}{$0.02 *$} \\
\hline & $\begin{array}{l}22-25 \\
\text { years }\end{array}$ & 22 & 8.09 & & & \\
\hline \multirow{2}{*}{ Brand price } & $\begin{array}{l}18-21 \\
\text { years }\end{array}$ & 78 & 11.44 & \multirow{2}{*}{99} & \multirow{2}{*}{0.034} & \multirow{2}{*}{0.84} \\
\hline & $\begin{array}{l}22-25 \\
\text { years }\end{array}$ & 22 & 11.32 & & & \\
\hline \multirow{2}{*}{$\begin{array}{c}\text { Brand } \\
\text { Appearance }\end{array}$} & $\begin{array}{l}18-21 \\
\text { years }\end{array}$ & 78 & 10.53 & \multirow{2}{*}{99} & \multirow{2}{*}{6.989} & \multirow{2}{*}{$0.01 * *$} \\
\hline & $\begin{array}{l}22-25 \\
\text { years }\end{array}$ & 22 & 9 & & & \\
\hline \multirow{2}{*}{ Satisfaction } & $\begin{array}{l}18-21 \\
\text { years }\end{array}$ & 78 & 22.25 & \multirow{2}{*}{99} & \multirow{2}{*}{3.451} & \multirow{2}{*}{0.06} \\
\hline & $\begin{array}{l}22-25 \\
\text { years }\end{array}$ & 22 & 20.04 & & & \\
\hline
\end{tabular}

Source: primary data

In table 3, ANOVA between group results for the effect of age on each dimension did not show any significant differences in terms of preference $($ Sig. $=0.9)$, brand price $($ sig. $=0.84)$ and satisfaction $($ sig. $=0.06)$ hence null hypothesis is accepted. Meanwhile significant differences were observed in the aspect of repurchase intention $(\mathrm{F}=$ 4.930, sig. $=0.02)$ and brand appearance $(F=6.989$, sig. $=$ 0.01). Hence null hypothesis is rejected.

Table 3: One-Way ANOVA result based on respondents' Educational degree

\begin{tabular}{|c|c|c|c|c|c|c|}
\hline Particulars & Degree & $N$ & Mean & $d f$ & $F$ & $\begin{array}{c}p \\
\text { Value }\end{array}$ \\
\hline \multirow{2}{*}{$\begin{array}{c}\text { Brand } \\
\text { preference }\end{array}$} & UG & 79 & 11.48 & \multirow{2}{*}{99} & \multirow{2}{*}{0.252} & \multirow{2}{*}{0.62} \\
\hline & PG & 21 & 11.14 & & & \\
\hline \multirow{2}{*}{$\begin{array}{l}\text { Repurchase } \\
\text { intention }\end{array}$} & UG & 79 & 9.6 & \multirow{2}{*}{99} & \multirow{2}{*}{3.246} & \multirow{2}{*}{0.07} \\
\hline & PG & 21 & 8.28 & & & \\
\hline \multirow[t]{2}{*}{ Brand price } & UG & 79 & 11.49 & \multirow{2}{*}{99} & \multirow{2}{*}{0.264} & \multirow{2}{*}{0.54} \\
\hline & PG & 21 & 11.17 & & & \\
\hline
\end{tabular}

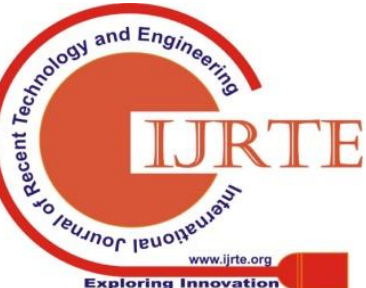




\begin{tabular}{|c|c|c|c|c|c|c|}
\hline $\begin{array}{c}\text { Brand } \\
\text { Appearance }\end{array}$ & UG & 79 & 10.53 & 99 & 7.12 & $001 * *$ \\
\cline { 2 - 4 } & PG & 21 & 9 & & & \\
\hline \multirow{2}{*}{ Satisfaction } & UG & 79 & 22.18 & \multirow{2}{*}{99} & 2.709 & 0.1 \\
\cline { 2 - 5 } & PG & 21 & 20.19 & & & \\
\hline
\end{tabular}

\section{Source: primary data}

In table 4, ANOVA between group results for the effect of degree on each dimension did not show any significant differences in terms of preference (Sig. $=0.62$ ), repurchase intention $\quad(\mathrm{sig} .=0.07)$, brand price $($ sig. $=0.54)$ and satisfaction (sig. $=0.10$ ). Hence null hypothesis is accepted. Meanwhile significant difference were observed in the aspect of brand appearance $(F=7.120$, sig. $=0.01)$. Hence null hypothesis is rejected.

\section{CONCLUSION}

The aim of this study was to investigate the determinants of brand preference towards Smartphones among college students in Coimbatore city, Tamil Nadu. The study examined mean difference between respondent's age, educational qualification and determinants of brand preference. The results of Analysis of Variance shows that there is no significant difference in terms of brand price, preference and satisfaction with reference to age and repurchase intention, brand appearance has significant difference between age and brand dimensions. Mean while, with the effect of degree of education on dimension of brand it did not show any significant differences in preference, repurchase intention, satisfaction and brand price. Similarly brand appearance has a significant difference with reference to degree of education. In this context the present study helps us to understand the importance of brand appearance, satisfaction, brand price, brand preference and repurchase intention. In the sum, brand preference plays a vital role among all types of people especially college students. In this situation, the Smartphones manufactures and producers have to concentrate and develop a strategy in order to win the hearts of the Smartphones customers.

\section{ACKNOWLEDGEMENT}

The authors would like to thank and acknowledge Indian Council of Social Science Research (ICSSR), New Delhi for providing contingency grant and sincere gratitude for all those people who have been associated with this research.

\section{REFERENCE}

1. Mulyanegara, R., \& Tsarenko, Y. (n.d.). Predicting brand preferences: An examination of the predictive power of consumer personality and values in the Australian fashion market. Journal of Fashion Marketing and Management, 13(3), 358-371.

2. Hawkins, D., Best, R., \& Coney, K. (2004). Consumer behavior: building marketing strategy. Irwin: McGraw-Hill.

3. Bloemer, J., \& Kasper, H. D. (1995). The Complex Relationship between Consumers Satisfaction and Brand preference. Journal of Economic Psychology, 16, 311-319.

4. Kohli, C., \& Thakor, M. (1997). Branding Consumer Goods: Insights from Theory and Practice. Journal of Consumer Marketing, 14, 206 209.

5. Venkatraman, V., Clithero, J., Fitzsimons, G., \& Huettel, S. (2012). New Scanner Data for Brand Marketers: How Neuroscience Can Help Better Understand Differences in Brand Preferences. Journal of Consumer Psychology, 22(1), 143-153.
6. Spillan, J., \& Harcar, T. (2013). A Comparative Study of Patriotism, Protectionism, Social Economic Conservatism between Indian and Vietnamese Consumers: The Effects of these Constructs on Buying Inclinations. Eurasian Journal of Business and Economics, 6(12), 126.

7. Gungor, M., \& Bilgin, F. (2011). Customer's Advisory, Organizational Openness and Capability: the Locus of Value Creation. Eurasian Journal of Business and Economics, 4(7), 81-97.

8. Jin, X., \& Weber, K. (2013). Developing and Testing a Model of Exhibition Brand Preference: The Exhibitors' Perspective. Tourism Management, 38, 94-104.

9. Veloutsou, C., \& Moutinho, L. (2009). Brand Relationships Through Brand Reputation and Brand Tribalism. Journal of Business Research, 62(3), 314-322.

\section{AUTHORS PROFILE}

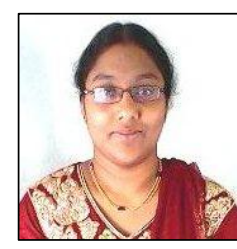

Biographical notes: G. Saranya is a $\mathrm{Ph} . \mathrm{D}$ research scholar in Department of Management Studies, Periyar University, Salem, Tamil Nadu, India. She completed her SSLC in 2005 and Higher secondary in 2007 from St. Joseph Matriculation Higher Secondary School, Salem. She pursued her B.B.A. (CA) Bachelor of Business Administration (Computer Applications) in April 2010 from Jairam Arts and Science College, Salem, affiliated to Periyar University, Salem, She completed M.B.A Master of Business Administration in April 2014 from Anna University, Chennai, M.Phil (Management Studies) Master of Philosophy in July 2016 from Periyar University, Salem and pursuing Doctor of Philosophy in Management Studies from January 2017 in Periyar University, Salem. Her Areas of Specialisation is Marketing and Human resource management. She has published 6 articles in UGC CARE Journals and two in Conference proceedings. She has presented 15 papers in conferences and seminars. She has participated in 12 workshops. She has awarded University Research Fellowship (URF) for the year 2018-2020 and Indian Council for Social Science Research (ICSSR), New Delhi, Contingency Grant Fellowship for the year 2019-2020.

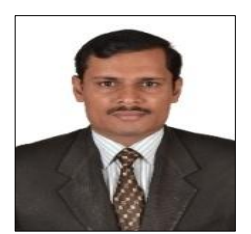

Biographical notes: G. Yoganandan is Associate Professor at Department of Management Studies, Periyar University, Salem, Tamil Nadu, India. He pursued his B.Sc Bachelor of Science (Chemistry) in April 1997 from Erode Arts College, Erode, affiliated to Bharathiar University, Coimbatore and Doctor of Philosophy in Management Studies in April 2014, from Anna University, Chennai. His Area of Specialisation is Marketing, International Marketing and Entrepreneurship. He has published 59 articles in peer-reviewed international journals. He has over 18 years of experience in teaching \& research and 2 years experience in textile export industry. His current area of research includes rural marketing, international marketing and entrepreneurship. He has guided 23 M.Phil scholars. Currently, he is guiding one Post Doctoral Fellow, 5 Ph.D research scholars while 2 research scholars have submitted their Ph. D thesis. He has completed a Major Research Project funded by Rajiv Gandhi National Institute of Youth Development, Sriperumpudur and an ongoing Major Research Project funded by ICSSR (under IMPRESS Scheme), New Delhi. He has presented 53 research papers national and international seminars and has acted as Chair person in 4 international conferences. He has given guest lecturers in more than 20 forums. He have participated in 11 FDPs and organized 15 programmes. He has received two awards for teaching and research. He has visited University of Kelaniya, Sri Lanka for International Conference. 